\title{
NEURON AND GLIAL CELL NUMBERS IN THE MEDIODORSAL THALAMIC NUCLEUS IN BRAINS OF SCHIZOPHRENIC SUBJECTS
}

\author{
Rune DamgaArd Nielsen, Maja ABitz And Bente PAKKenBerg \\ Research Laboratory for Stereology and Neuroscience, Bispebjerg University Hospital \\ e-mail: forsklab@bbh.regionh.dk \\ (Accepted August 1, 2008)
}

\begin{abstract}
Several stereological studies of schizophrenic subjects have shown reduction in both the total number of neurons and in the total volume of the mediodorsal thalamic nucleus (MD). This is in contrast to other studies in that no differences have been found. Using systematic random sampling and an optical fractionator design, the total number of neuron and glial cells in the $\mathrm{MD}$ subdivisions: parvocellular $\left(\mathrm{MD}_{\mathrm{PC}}\right)$, magnocellular $\left(\mathrm{MD}_{\mathrm{MC}}\right)$, and densocellular $\left(\mathrm{MD}_{\mathrm{DC}}\right)$ were counted in brains from 9 schizophrenic and 8 control subjects. The control subjects were age, height and body-weight matched to the schizophrenic subjects. We found the neuronal numbers in the schizophrenic subjects to range more than a factor of two, from 3.68 to $9.22 \times 10^{6}$. This is in contrast to the control subjects, who ranged from 5.24 to $7.10 \times 10^{6}$ in neuronal cell numbers. Within our inhomogeneous sample, some schizophrenic subjects thus exhibited relative high total neuron numbers in MD, while others exhibited relative low neuron numbers. The result is in line with the heterogeneity of this severe mental disease and may help to explain why different research groups get different results. The major limitation in this study is the small number of brains of schizophrenic subjects with a high degree of inhomogeneity in length of disease and age of onset. The debates of the comparison of the neurons in the MD in brains of schizophrenic subjects and control subjects and the possible impact of this variance on the disease are still not complete.
\end{abstract}

Keywords: cell counting; neurostereology; optical fractionator; thalamus.

\section{INTRODUCTION}

Historically, some of the distinctive clinical features of schizophrenic patients include perceptional distortion such as psychotic symptoms with psychomotor disturbances and cognitive, emotional and social dysfunction. The various positive and negative symptoms indicate a fragmentation of such higher cerebral functions as emotional control, integration and separation of thought processes and the definition of the individual's autonomy. In 1895, Monakow suggested the mediodorsal thalamic nucleus (MD) was linked to the cognitive and emotional life of an individual (Monakow et al., 1895) and for many decades the MD has been the focus of attention in the search for specific underlying pathology to the schizophrenic illness (Bäumer, 1954).

Some distinctive characteristics make the MD stand out in humans (Armstrong, 1990): Compared to apes the human MD is relatively large with respect to size and total neuron number. The MD is also the second largest complex in the human thalamus. The thalamic function of relaying or "gating" sensory input
(Steriade et al., 1997), and more specifically the MDs numerous reciprocal connections to the dorsolateral prefrontal cortex (Brodmann's area 9, 10 and 46) and afferent connections to the striatum, basal ganglia and limbic system is well-documented (Goldman-Rakic and Porrino, 1985; Alexander et al., 1990; Armstrong, 1990; Jones, 1997b; Steriade et al., 1997; Jones, 2002; Erickson and Lewis, 2004). Several studies concentrating on mapping the anatomy, projections and afferent input to the MD have been the basis of a topographical map of the nucleus (Goldman-Rakic and Porrino, 1985; Alexander et al., 1990; Armstrong, 1990; Jones, 1997a; Jones, 1997b; Steriade et al., 1997; Jones, 2002; Erickson and Lewis, 2004). Histologically two populations of neurons are described for the human thalamus (Dewulf 1971; Armstrong, 1990; Steriade et al., 1997), including the MD. One population containing $20-40 \%$ of the neurons represents small neurons that may for cases be presumably inhibitory (gabaergic) interneurons with projections restricted to specific thalamic nuclei. The second population of neurons are larger and may in most cases be excitatory relay neurons projecting to the cerebral cortex. Three different subregions (or 
subnuclei) have been ascribed to the MD (Dewulf, 1971; Hirai and Jones, 1989; Armstrong, 1990; Jones, 1997a; Jones, 1997b), an anteromedial magnocellular $\left(\mathrm{MD}_{\mathrm{MC}}\right)$, a dorsolateral parvocellular $\left(\mathrm{MD}_{\mathrm{PC}}\right)$ and a posterolateral densocellular $\left(\mathrm{MD}_{\mathrm{DC}}\right)$ or multiform portion. The nomenclature for these subregions varies throughout the literature, and even though it partly describes general morphological characteristics of a given region, it does not necessarily apply to the neuronal size or packing density (Armstrong, 1990). Each region, however, has its own specific projections, which ratifies the segregation (Goldman-Rakic and Porrino, 1985; Alexander et al., 1990; Armstrong, 1990; Jones, 1997b; Steriade et al., 1997; Jones, 2002; Erickson and Lewis, 2004); $\mathrm{MD}_{\mathrm{MC}}$ is dominated by inputs from the olfactory and entorhinal cortices, but it also receives input from the amygdala; $\mathrm{MD}_{\mathrm{MC}}$ projects to the ventromedial and orbital cortex in the frontal lobe. $\mathrm{MD}_{\mathrm{PC}}$ receives input from the superior colliculus, and other midbrain structures and projects to dorsal and lateral areas of the prefrontal cortex. $\mathrm{MD}_{\mathrm{DC}}$ projects to the striatum, premotor cortical areas, the frontal eye fields (Brodmann's area 8) and the supplementary frontal eye fields. Inhibitory input reaches all three subregions from the ventral pallidum, pars reticulata of substantia nigra and the thalamic reticular nucleus.

Several studies have described alterations specifically in the MD of schizophrenic subjects. Among the most compelling findings are a reduction by $27-40 \%$ in the total number of neurons and a volume reduction by 9-25\% (Pakkenberg, 1990; Pakkenberg, 1992; Popken et al., 2000; Young et al. 2000; Byne et al., 2002; Danos et al., 2003). Speculations on the cause of these findings include anterograde axon degeneration and/or decrease in dendritic spine density in cortical projection areas following a loss of thalamic neurons. Further, degeneration of thalamic neurons and/or gliosis following retrograde degeneration of cortical MD afferents, possibly caused by smaller lesions to frontal lobe areas. The latter could both account for a loss of thalamic neurons and/or diminished somal size (Jones, 1997b).

Using stereological methods, our aim was to quantitate the total number of neurons and glial cells in the total MD and its subdivisions in a new series of brains from schizophrenic patients most of whom had a late debut, to determine if these numbers are the same in schizophrenic subjects and control subjects.

\section{MATERIALS AND METHODS}

All brains were collected from 1975-1997 from autopsied individuals in accordance with the Danish laws on autopsied human tissue. Previously published stereological studies on the prefrontal cortex in schizophrenics include Thune et al. (2001) and Stark et al. (2004). The study initially included 12 (5 female and 7 male) subjects clinically diagnosed with schizophrenia and 10 (6 female and 4 male) control subjects. Due to strict exclusion criteria, five brains were excluded due to various artefacts. The demographic and clinical data for the schizophrenic and control subjects are listed in Table 1, while Table 2 shows the postmortem data. The schizophrenic patients were diagnosed independently by two senior psychiatrists at Sct. Hans Psychiatric Hospital in Roskilde, Denmark, using DSM-IV criteria (Diagnostic and Statistical Manual, $4^{\text {th }}$ Ed.). All patients had been hospitalised and treated with neuroleptic medication. Some were also treated with insulin comas or shock treatment for a variable period of time. Neither of the diagnostic groups had any history of alcohol or abuse, no head injury and exhibited no prehospital CNS symptoms. Note that we have recorded the age at first admission for the psychiatric patient (Table 1) instead of age of onset, but most of the patients were admitted to the psychiatric ward within months of first symptoms. The control subjects had no neurological or psychiatric disorders. All autopsies were carried out within 20-72 hrs postmortem, and the brains were subsequently fixed in $0.1 \mathrm{M}$ sodium phosphate buffered $(\mathrm{pH} 7.2)$ $4 \%$ formaldehyde for at least 5 months. Although there was a substantial difference in length of fixation in formalin and some difference in the post-mortem interval between the two groups, we encountered no correlation between the quality of the tissue/counting conditions and these two parameters.

The initial sectioning was carried out, sampled, and coded by individuals with no further involvement with the present study. Staining of the sections was delayed until the time of usage in a particular study, and it was carried out on coded sections by individuals who were not involved in the MD delineation or cell counting. The delineation of MD and its subregions was done on coded sections by two individuals. The interobserver variability was $6-7 \%$. 
Table 1. Demographic and clinical characteristics of schizophrenic and control subjects.

\begin{tabular}{|c|c|c|c|c|c|c|c|c|}
\hline Group & $\begin{array}{l}\text { Age } \\
\text { (yrs) }\end{array}$ & Sex & $\begin{array}{l}\text { Body } \\
\text { height } \\
\text { (cm) }\end{array}$ & $\begin{array}{l}\text { Body } \\
\text { weight } \\
\text { (kg) }\end{array}$ & $\begin{array}{l}\text { Duration of } \\
\text { psychiatric } \\
\text { hospital. } \\
\text { (yrs) }\end{array}$ & $\begin{array}{l}\text { Age at } \\
\text { first } \\
\text { admiss. } \\
\text { (yrs) }\end{array}$ & Subdiagnosis & $\begin{array}{l}\text { Duration } \\
\text { of neuro- } \\
\text { leptic } \\
\text { treatment } \\
\text { (yrs) }\end{array}$ \\
\hline \multicolumn{9}{|c|}{ Schizophrenic subjects } \\
\hline 1 & 30 & $\mathrm{M}$ & 178 & 70 & $<1$ & 26 & Simplex & 5 \\
\hline 2 & 56 & $\mathrm{M}$ & 174 & 90 & $3-4$ & 50 & Paranoid & 8 \\
\hline 3 & 56 & $\mathrm{M}$ & 170 & 81 & $2-3$ & 39 & Paranoid & 13 \\
\hline 4 & 74 & $\mathrm{~F}$ & 158 & 52 & $2-3$ & 52 & Paranoid & 22 \\
\hline 5 & 75 & $\mathrm{M}$ & 165 & 55 & 55 & 21 & Simplex & 19 \\
\hline 6 & 78 & $\mathrm{M}$ & 178 & 70 & 43 & 35 & Simplex & 15 \\
\hline 7 & 80 & $\mathrm{~F}$ & 160 & 61 & $1-2$ & 31 & Paranoid & 38 \\
\hline 8 & 85 & $\mathrm{~F}$ & 170 & 58 & 49 & 46 & $\begin{array}{l}\text { Hebephrenic, } \\
\text { catatonic }\end{array}$ & 39 \\
\hline 9 & 85 & $\mathrm{~F}$ & 165 & 50 & $1-2$ & 45 & Paranoid & 19 \\
\hline Mean & 68.8 & & 169 & & & & & \\
\hline Range & $30-85$ & & $158-178$ & $50-90$ & & & & \\
\hline \multicolumn{9}{|c|}{ Control subjects } \\
\hline 1 & 43 & $\mathrm{M}$ & 175 & 82 & & & & \\
\hline 2 & 64 & $\mathrm{~F}$ & 154 & 50 & & & & \\
\hline 3 & 65 & $\mathrm{M}$ & 173 & 85 & & & & \\
\hline 4 & 70 & $\mathrm{~F}$ & 169 & 54 & & & & \\
\hline 5 & 71 & $\mathrm{M}$ & 175 & 78 & & & & \\
\hline 6 & 75 & $\mathrm{~F}$ & 159 & 60 & & & & \\
\hline 7 & 75 & $\mathrm{~F}$ & 172 & 56 & & & & \\
\hline 8 & 85 & $\mathrm{~F}$ & 159 & 39 & & & & \\
\hline Mean & 68.5 & & 167 & 63 & & & & \\
\hline Range & $43-85$ & & $154-175$ & $39-85$ & & & & \\
\hline
\end{tabular}

\section{TISSUE PREPARATION}

The meninges were removed, and the cerebellum and brainstem detached at the level of the third cranial nerve. Brains of all subjects, schizophrenic and controls, underwent a full neuropathological autopsy screening, which revealed no pathology such as bleeding, infection, degeneration, tumors or metastases in any part of the cerebrum. The entire left or right hemisphere was cut coronally into $2-3$ slices, each $\sim 2.5 \mathrm{~cm}$ thick, dehydrated and embedded in paraffin in a Leica ASP300 tissue processor. The brains were cut into parallel sections of equal thickness of $40 \mu \mathrm{m}$, using a Leica microtome, resulting in a total number of about 2500-3000 sections from each hemisphere. A wetted filter paper was placed on the paraffin block allowing collection of the sampled section without using water baths. When the section stuck to the filter paper, it was mounted on a double silane coated microscope slide by placing the paper with the section down on the slide, pressing gently on the paper side with a printing roller (for illustration see Eriksen and Pakkenberg, 2007). Using this procedure we can exclude tissue deformation usually taking place in water baths, and the tissue section height is $\sim 40 \mu \mathrm{m}$ post processing. This initial thick slicing was effectively random due to the central and therefore hidden location and size of the thalamus. The sampled sections were mounted on double silane coated glass slides and instantly dried at $40 \mathrm{C}$ for $24 \mathrm{hrs}$. The sections were then heated to $60 \mathrm{C}$ for $30 \mathrm{~min}$. prior to staining, dewaxed in xylene for $45 \mathrm{~min}$., followed by $15 \mathrm{~min}$. in $99 \%$ ethanol, $10 \mathrm{~min}$. in $96 \%$ ethanol, $5 \mathrm{~min}$. in $70 \%$ ethanol and $5 \mathrm{~min}$. in distilled water. The sections were stained using a modified Giemsa stain containing 25 $\mathrm{ml}$ Giemsa stock solution ("Merck", Germany, product 1.09204 ) and $250 \mathrm{ml}$, potassium-hydrogen-phosphate at $\mathrm{pH} 4.5$, which was filtered before use. Finally the sections were differentiated with $0.5 \%$ acetic acid and dehydrated through $96 \%$ ethanol for 1-5 min., 99\% ethanol for 5-10 min., and xylene for $15 \mathrm{~min}$. 
Table 2. Postmortem data of schizophrenic and control subjects.

\begin{tabular}{|c|c|c|c|c|c|c|}
\hline Group & Cause of death & $\begin{array}{l}\text { Brain } \\
\text { weight } \\
\text { (g) }\end{array}$ & $\begin{array}{l}\text { Termin- } \\
\text { al period } \\
\text { (days) }\end{array}$ & $\begin{array}{l}\text { Post- } \\
\text { mortem } \\
\text { interval } \\
\text { (hrs) }\end{array}$ & $\begin{array}{l}\text { Fixation } \\
\text { period } \\
\text { (months) }\end{array}$ & $\begin{array}{l}\text { Hemi- } \\
\text { sphere } \\
\text { sampled }\end{array}$ \\
\hline \multicolumn{7}{|c|}{ Schizophrenic subjects } \\
\hline 1 & Suicide & 1420 & 0.1 & 66 & 90 & $\mathrm{R}$ \\
\hline 2 & $\mathrm{AMI}^{1}$ & 1470 & 2 & 24 & 156 & $\mathrm{~L}$ \\
\hline 3 & Acute bronchitis & 1320 & 3 & 72 & 125 & $\mathrm{R}$ \\
\hline 4 & Colon Cancer & 1220 & 3 & 24 & 34.5 & $\mathrm{R}$ \\
\hline 5 & $\mathrm{AMI}^{1}$ & $920^{2}$ & 3 & 29 & 301 & $\mathrm{R}$ \\
\hline 6 & $\mathrm{AMI}^{1}$ & 1260 & 0.1 & 20 & 180 & $\mathrm{R}$ \\
\hline 7 & Breast Cancer & 1100 & 18 & 48 & 126 & $\mathrm{R}$ \\
\hline 8 & Pneumonia & 1100 & 18 & 45 & 125 & $\mathrm{R}$ \\
\hline 9 & $\mathrm{AMI}^{1}$ & 1070 & 0.1 & 23.5 & 48 & $\mathrm{~L}$ \\
\hline Mean & & 1202 & & 39 & 132 & \\
\hline Range & & $1070-1470$ & & $20-72$ & $34.5-301$ & \\
\hline \multicolumn{7}{|c|}{ Control subjects } \\
\hline 1 & $\mathrm{AMI}^{1}$ & 1560 & - & 24 & 65 & $\mathrm{R}$ \\
\hline 2 & $\mathrm{AMI}^{1}$ & 1240 & 0.1 & 24 & 90 & $\mathrm{R}$ \\
\hline 3 & $\mathrm{AMI}^{1}$ & 1420 & 0.1 & 24 & 66 & $\mathrm{R}$ \\
\hline 4 & $\mathrm{AMI}^{1}$ & 1334 & 0.1 & 33 & 96 & $\mathrm{R}$ \\
\hline 5 & $\mathrm{AMI}^{1}$ & 1380 & 0.1 & 48 & 12 & $\mathrm{R}$ \\
\hline 6 & $\mathrm{AMI}^{1}$ & 1150 & - & 24 & - & $\mathrm{R}$ \\
\hline 7 & $\begin{array}{l}\text { Congestive heart } \\
\text { failure }\end{array}$ & 1138 & 0.1 & 35 & 91 & $\mathrm{~L}$ \\
\hline 8 & $\mathrm{AMI}^{1}$ & 1180 & 14 & 24 & 129 & $\mathrm{R}$ \\
\hline Mean & & 1300 & & 29.5 & 78 & \\
\hline Range & & $1138-1560$ & & $24-48$ & $12-129$ & \\
\hline
\end{tabular}

${ }^{1}$ AMI: Acute myocardial infarction. ${ }^{2}$ The occipital lobe was not included in the total brain weight

\section{Delineation of the MD thalamus and subregions}

There remain varying definitions of the boundaries of the MD (Dewulf, 1971; Hirai and Jones, 1989; Armstrong, 1990; Jones, 1997a). In this study we have based our delineations on the cyto- and myeloarchitectonic criteria defined by Hirai and Jones (1989). Initially the sections were studied through an Olympus stereomicroscope (VMZ 1x-4x) and the MD and subregions were demarcated directly on the coverslip using a fine permanent ink liner. The internal border of the ink demarcations represented the specified area and was used as reference for the final demarcations. Some section series were delineated by us and reevaluated by Edward G. Jones and adjusted accordingly. Immediately prior to counting, the final demarcations were made directly on the monitor with a mouse device using the CAST Grid 2.0 stereological software by Olympus, Denmark.

For the anterior part of MD, which is initially situated just caudal and ventral to the anterior ventral nucleus; lateral to the lateral dorsal nucleus; the internal medullar lamina (IML) spreads ventrally, expands over the anterior surface of the MD and then continues posterior as thin dispersed strips on either side of the mammillothalamic tract (MTT). Throughout the middle part of the MD it is virtually encapsulated anteriorly, ventrally and laterally by the IML that also sends extensions to much of its dorsal and medial surfaces. As part of the IML the cells of the paracentral and central lateral nuclei clearly delineate the lateral boundary of the MD for most of its rostralcaudal extent. At most posteriorly levels the caudal part of the MD is bordered by the parafascicular and centre median nuclei. Medially the MD is lined with $3^{\text {rd }}$ ventricular ependyma lying immediately adjacent to the $3^{\text {rd }}$ ventricle, except where the paraventricular nucleus is interposed. Given these relatively distinct features, demarcating the external borders of the MD presented no serious problem, except perhaps for the most posterior level of the MD, adjacent to the anterior part of the pulvinar, where the IML breaks up into clustered aggregates that invade the MD. 
Interior divisions of the MD include the magnocellular $\left(\mathrm{MD}_{\mathrm{MC}}\right)$, the parvocellular $\left(\mathrm{MD}_{\mathrm{PC}}\right)$, and the densocellular $\left(\mathrm{MD}_{\mathrm{DC}}\right)$ subregions. $\mathrm{MD}_{\mathrm{MC}}$ occupies the anteromedial aspect of MD and is composed of relatively large, deeply stained neurons in a densely packed homogeneous neuropil. Most of the dorsolateral area of the $\mathrm{MD}$ is made up of the $\mathrm{MD}_{\mathrm{PC}}$ that possesses somewhat smaller variably stained neurons in a looser neuropil broken up by bundles of fibers (Dewulf, 1971; Hirai and Jones, 1989). Laterally and posterior the $\mathrm{MD}$ is enveloped by the $\mathrm{MD}_{\mathrm{DC}}$, in which we include the paralamellar part of the MD (Jones, 1997a). The neurons here are densely stained and resemble those of the central lateral nucleus (CL).

\section{Neuron and glial cell differentiation}

We chose to identify large neurons, $N_{l}$, small neurons, $N_{2}$, and glial cells, G, purely on morphology and size, although the distinction between the largest glial cells and the smallest neurons is not a trivial problem. In this study the neurons are distinguished from astrocytes and oligodendrocytes in Giemsa stained sections by criteria such as diffuse and even chromatin pattern, somal size, size and shape of the nucleus, a clearly visible nucleolus, and a well defined surrounding cytoplasm. Analyzing the thalamic neurons by somal size alone show a bimodal frequency distribution with very little overlap between the smallest of the large neurons and the largest of the small neurons (Dewulf, 1971; Dorph-Petersen et al., 2004). Others have shown that up to $40 \%$ of the neurons in the MD are small presumably inhibitory (gabaergic) neurons whereas the large neurons are presumed to be predominantly excitatory projection neurons to the cerebral cortex (Dewulf, 1971; DorphPetersen et al., 2004). A clear identification of the two types of neurons is only possible using immunocytochemical techniques, which has not been applied to this study, so the differentiation into large (projection) neurons versus small (inhibitory) neurons is based only on size. See Fig. 1 for an illustration of the different cell types. In the following we will refer to the two types of neurons only as large or small. Glial cells, i.e., astrocytes, oligodendrocytes and microglia, were counted as one entity.

\section{Counting method}

The design applied to this study is the optical fractionator. The fractionator sampling scheme enables you to quantify the total cell number of a structure unaffected by tissue changes such as shrinkage. It is a requirement that the entire undamaged structure is available for sampling (Gundersen, 1986). The left or

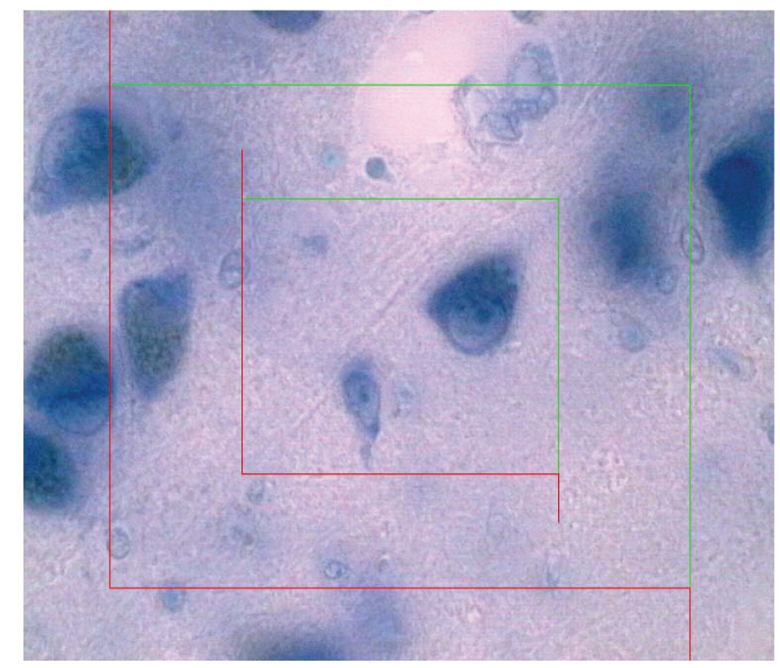

Fig. 1. A 40- $\mu$ m-thick Giemsa-stained section of the mediodorsal thalamic nucleus (MD) showing a large relay neuron in the upper right corner of the internal counting frame. Adjacent to that, lower and left, is seen a small interneuron.

right entire MD was sampled from a series of sections with a random starting point and a predetermined periodicity: the section-sampling fraction (ssf) of between $1 / 40^{\text {th }}$ and $1 / 60^{\text {th }}$, depending on the number of sections of the entire MD. This resulted in 6-9 sections being sampled from each MD. The sections were examined through a $60 \mathrm{x}$ oil immersion objective (Olympus, 1.40 numerical aperture) using an Olympus BX50 microscope equipped with a Heidenhain microcator, a motorized specimen stage (PRIOR ProScan) and an attached video camera. The video camera connected to a computer running the Computer Assisted Stereological Test Grid System, CAST Grid System, version 2.0, Olympus, Denmark, and the image was displayed on a 17 inches flat screen monitor (Dell Technologies). Using the stereological software the cells were counted directly in a known fraction of each region using the optical disector in a systematic random pattern. The area of the 2D counting frame was known relative to the area associated with each movement in the $\mathrm{x}$-y-direction, the area sampling fraction (asf). The size of the counting frame and the $\mathrm{x}-\mathrm{y}$ distance were adjusted in each brain to count approximately 100-200 cells of each type per region. Consequently the $\mathrm{x}-\mathrm{y}$ interval varied from $900 \mu \mathrm{m}$ in $\mathrm{MD}_{\mathrm{PC}}$ to $500-600 \mu \mathrm{m}$ in $\mathrm{MD}_{\mathrm{MC}}$ and $\mathrm{MD}_{\mathrm{DC}}$. The fixed height of the disector, $h$, was chosen to be $20 \mu \mathrm{m}$ and the mean section thickness, $t$, in each brain was estimated from measurements of $t$ made at every $4^{\text {th }}$ disector containing sampled cells. The sections were cut at $40 \mu \mathrm{m}$ with a final mean 
section thickness of $39 \mu \mathrm{m}(33-43 \mu \mathrm{m})$. Due to the relatively small shrinkage, upper and lower guard zones were set at 5 and $15 \mu \mathrm{m}$, respectively. The Heidenhain microcator used to measure movements in the z-axis had a precision of $0.5 \mu \mathrm{m}$. Within the guard zones the cells were counted when the nucleus came into focus inside the counting frame at a final magnification of about 1480X. Nuclei touching the limits of the lower guard zone and left and bottom exclusion lines of the counting frame were not counted. The height sampling fraction (hsf) was the heigth of the disector to the $q_{i}$-minus weighted section thickness (Dorph-Petersen et al., 2001). The unilateral number of cells, in MD or one of its subregions, was calculated as

$$
N=\frac{1}{s s f} \times \frac{1}{\text { asf }} \times \frac{1}{h s f} \times \sum Q^{-}
$$

where $\Sigma Q^{-}$denotes the total number of cells counted in all the disectors of the region being counted.

The upper right corner in each frame were also recorded to obtain the volume of the total MD and its subdivisions using the Cavalieri's principle.

All counting was carried out by the same investigator. As part of a different study, a second observer subsequently counted all three cell types in the same MD subregions in four of the brains and the interobserver variability was between $6-7 \%$. The subregions counted by the second observer were defined by the exact same delineations as those used by the first observer.

\section{Precision of the estimate}

A mean of 580 cells, of each cell type, in an average of 260 disectors were counted per brain (for $\mathrm{MD}_{\mathrm{PC}}$ : 220 cells in an average of 102 disectors; for $\mathrm{MD}_{\mathrm{MC}}$ : 194 cells in an average of 86 disectors; for $\mathrm{MD}_{\mathrm{DC}}: 167$ cells in an average of 73 disectors). The coefficient of error was estimated from the CE contribution from section thickness and equations 20-22, Gundersen et al., 1999. The final estimate of the sum of the total number of cells in the subdivisions of MD had a mean $\mathrm{CE}$ of $6,2 \%, 6,0 \%$, and $7,0 \%$ for $\mathrm{MD}_{\mathrm{PC}}, \mathrm{MD}_{\mathrm{MC}}$, and $\mathrm{MD}_{\mathrm{DC}}$ respectively, with no significant difference observed between the controls and the schizophrenic group. The sampling is considered optimal, when the observed variance of the individual estimate, $\mathrm{CE}^{2}$, is less than half the observed biological variation, $\mathrm{CV}^{2}$, for coefficient of variation, $\mathrm{CV}$, equal to $\mathrm{SD} /$ mean. For $\mathrm{CV}$ estimates, see Table 3.

\section{Statistical methods}

The results of the two diagnostic groups were compared with regard to their mean using the unpaired two-tailed Student's t-test performed at the 0,05 significance level. If the equal variance test failed we performed a non-parametric test (Mann-Whitney Utest) that compares the two diagnostic groups with respect to the ranks of the dependent variable.

Table 3. Results of the stereological analyses.

\begin{tabular}{|c|c|c|c|c|c|c|c|c|c|c|c|c|c|}
\hline & $\begin{array}{l}\mathrm{N}_{\mathrm{TOT}} \\
\left(10^{6}\right) \\
\end{array}$ & $\begin{array}{l}\mathrm{N}_{1} \\
\left(10^{6}\right)\end{array}$ & $\begin{array}{l}N_{2} \\
\left(10^{6}\right)\end{array}$ & $\begin{array}{l}\mathrm{N}_{\mathrm{MD}(\mathrm{PC})} \\
\left(10^{6}\right)\end{array}$ & $\begin{array}{l}\mathrm{N}_{\mathrm{MD}(\mathrm{MC})} \\
\left(10^{6}\right)\end{array}$ & $\begin{array}{l}\mathrm{N}_{\mathrm{MD}(\mathrm{DC})} \\
\left(10^{6}\right)\end{array}$ & $\begin{array}{l}\mathrm{N}_{\mathrm{MD}(\mathrm{PC}) 1} \\
\left(10^{6}\right)\end{array}$ & $\begin{array}{l}\mathrm{N}_{\mathrm{MD}(\mathrm{MC}) 1} \\
\left(10^{6}\right)\end{array}$ & $\begin{array}{l}\mathrm{N}_{\mathrm{MD}(\mathrm{DC}) 1} \\
\left(10^{6}\right)\end{array}$ & $\begin{array}{l}\mathrm{N}_{\mathrm{MD}(\mathrm{PC}) 2} \\
\left(10^{6}\right)\end{array}$ & $\begin{array}{l}\mathrm{N}_{\mathrm{MD}(\mathrm{MC}) 2} \\
\left(10^{6}\right)\end{array}$ & $\begin{array}{l}\mathrm{N}_{\mathrm{MD}(\mathrm{DC}) 2} \\
\left(10^{6}\right)\end{array}$ & $\begin{array}{l}\mathrm{G}_{\mathrm{TOT}} \\
\left(10^{6}\right) \\
\end{array}$ \\
\hline \multicolumn{14}{|c|}{ e } \\
\hline \multicolumn{14}{|c|}{ Schizophrenia } \\
\hline Mean & 6.84 & 4.04 & 2.80 & 3.94 & 1.72 & 1.18 & 2.27 & 1.10 & 0.67 & 1.67 & 0.62 & 0.51 & 40.22 \\
\hline $\mathrm{SD}$ & 1.91 & 1.17 & 0.76 & 1.19 & 0.55 & 0.49 & 0.71 & 0.34 & 0.28 & 0.52 & 0.23 & 0.22 & 15.78 \\
\hline $\mathrm{CV}^{1}$ & 0.28 & 0.29 & 0.27 & 0.30 & 0.32 & 0.42 & 0.31 & 0.31 & 0.42 & 0.31 & 0.37 & 0.43 & 0.39 \\
\hline \multicolumn{14}{|c|}{ Control } \\
\hline Mean & 6.25 & 3.81 & 2.44 & 3.81 & 1.63 & 0.93 & 2.27 & 0.99 & 0.55 & 1.54 & 0.52 & 0.38 & 43.85 \\
\hline SD & 0.66 & 0.52 & 0.24 & 0.65 & 0.51 & 0.28 & 0.43 & 0.30 & 0.14 & 0.33 & 0.22 & 0.15 & 5.86 \\
\hline $\mathrm{CV}^{1}$ & 0.11 & 0.14 & 0.098 & 0.17 & 0.31 & 0.30 & 0.19 & 0.30 & 0.25 & 0.21 & 0.42 & 0.40 & 0.13 \\
\hline
\end{tabular}

$\mathrm{N}_{1}$ : Large neurons; $\mathrm{N}_{2}$ : Small neurons; TOT: Total neuron number of the MD; 1: Large neurons; 2: Small neurons; MD(PC): Parvocellular subregion of the MD; MD(MC): Magnocellular subregion of the MD; MD(DC): Densocellular subregion of the MD; $\mathrm{G}_{\mathrm{TOT}}$ : Total glial cell number.

${ }^{1} C V=S D /$ Mean 


\section{RESULTS}

The calculated unilateral number of neurons and glial cells in MD and its subregions are shown in Table 3 and Figs. 2 and 3. We found no significant difference in the total neuron number for the entire MD ( $p=0.42$; Mann-Whitney U-test: $p=0,41)$ or for any of its subregions $\left(\mathrm{MD}_{\mathrm{PC}}: \mathrm{p}=0.78\right.$; $\mathrm{MD}_{\mathrm{MC}}: \mathrm{p}=$ $0.75 ; \mathrm{MD}_{\mathrm{DC}}: \mathrm{p}=0.22$ ). The same was observed for the glial cells, as no significant change in the total number was observed $\left(\mathrm{MD}_{\mathrm{TOT}}: \mathrm{p}=0.55 ; \mathrm{MD}_{\mathrm{PC}}: \mathrm{p}=\right.$ $\left.0.53 ; \mathrm{MD}_{\mathrm{MC}}: \mathrm{p}=0.38 ; \mathrm{MD}_{\mathrm{DC}}: \mathrm{p}=0.69\right)$. The same was true for the two types of neurons (large neurons, $\mathrm{N}_{1}: \mathrm{MD}_{\text {Tот }}: \mathrm{p}=0.61 ; \mathrm{MD}_{\mathrm{PC}}: \mathrm{p}=0.99 ; \mathrm{MD}_{\mathrm{MC}}: \mathrm{p}=$ $0.47 ; \mathrm{MD}_{\mathrm{DC}}: \mathrm{p}=0.30$; small neurons, $\mathrm{N}_{2}: \mathrm{MD}_{\mathrm{TOT}}: \mathrm{p}=$ 0.23; Mann-Whitney U-test: $p=0,39$; $\mathrm{MD}_{\mathrm{PC}}: \mathrm{p}=$ $0.57 ; \mathrm{MD}_{\mathrm{MC}}: \mathrm{p}=0.40 ; \mathrm{MD}_{\mathrm{DC}}: \mathrm{p}=0.17$ ).

The calculated volume for the total MD and its subregions are shown in Table 4 . We found no significant difference in the total volume of the MD $(p=0.66$; Mann-Whitney U-test: $\mathrm{p}=0.53)$ of for any of its subregions (MDPC: $\mathrm{p}=0.51$; Mann-Whitney Utest: $\left.p=0.19 ; \mathrm{MD}_{\mathrm{MC}}: \mathrm{p}=0.18 ; \mathrm{MD}_{\mathrm{DC}}: \mathrm{p}=0.70\right)$.

A multivariance analysis showed no correlation between total number of neurons and brain weight, age of subject, length of hospitalization, age at debut, years of treatment, length of terminal period, PMI or length of fixation in formalin. The power was low because of the low number of subjects.

Table 4. Results of the volume analyses.

\begin{tabular}{|c|c|c|c|c|}
\hline & $\begin{array}{l}\mathrm{V}_{\text {TOT }} \\
\left(\mathrm{mm}^{3}\right)\end{array}$ & $\begin{array}{l}\mathrm{V}_{\mathrm{MD}(\mathrm{PC})} \\
\left(\mathrm{mm}^{3}\right)\end{array}$ & $\begin{array}{l}\mathrm{V}_{\mathrm{MD}(\mathrm{MC})} \\
\left(\mathrm{mm}^{3}\right)\end{array}$ & $\begin{array}{l}\mathrm{V}_{\mathrm{MD}(\mathrm{DC})} \\
\left(\mathrm{mm}^{3}\right)\end{array}$ \\
\hline \multicolumn{5}{|l|}{ Group } \\
\hline \multicolumn{5}{|c|}{ Schizophrenia } \\
\hline Mean & 331 & 268 & 39 & 24 \\
\hline SD & 148 & 142 & 12 & 11 \\
\hline $\mathrm{CV}$ & 0.45 & 0.53 & 0.30 & 0.45 \\
\hline \multicolumn{5}{|c|}{ Control } \\
\hline Mean & 384 & 310 & 52 & 22 \\
\hline SD & 133 & 115 & 23 & 11 \\
\hline $\mathrm{CV}$ & 0.35 & 0.37 & 0.43 & 0.49 \\
\hline
\end{tabular}
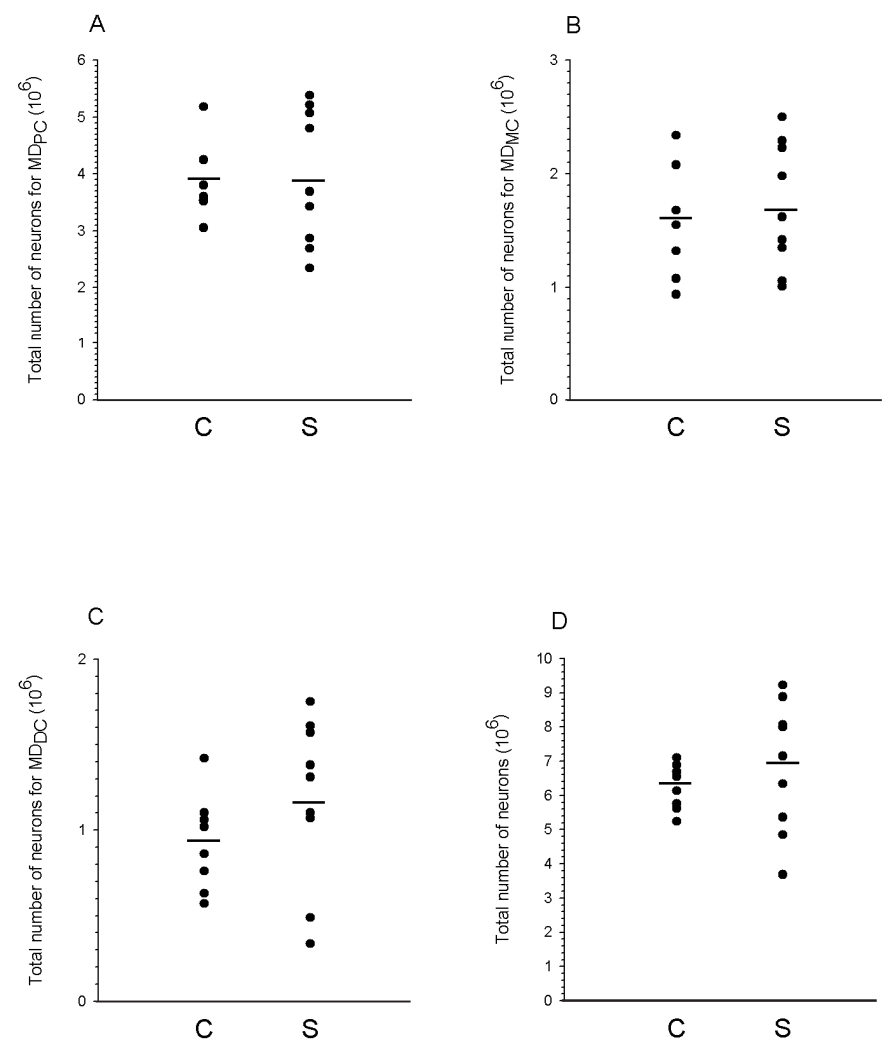

Fig. 2. Scatterplots of the estimates of the total number of neurons in $M D$ and subregions for control $(C)$ subjects and subjects with schizophrenia (S). Horizontal lines indicate mean values. A: Estimates of the total number of neurons in the parvocellular region of $M D\left(M D_{P C}\right)$. B: Estimates of the total number of neurons in the magnocellular region of $M D\left(M D_{M C}\right)$. C: Estimates of the total number of neurons in the densocellular region of $M D\left(M D_{D C}\right)$. D: Estimates of total neuron number in the entire $M D$. 

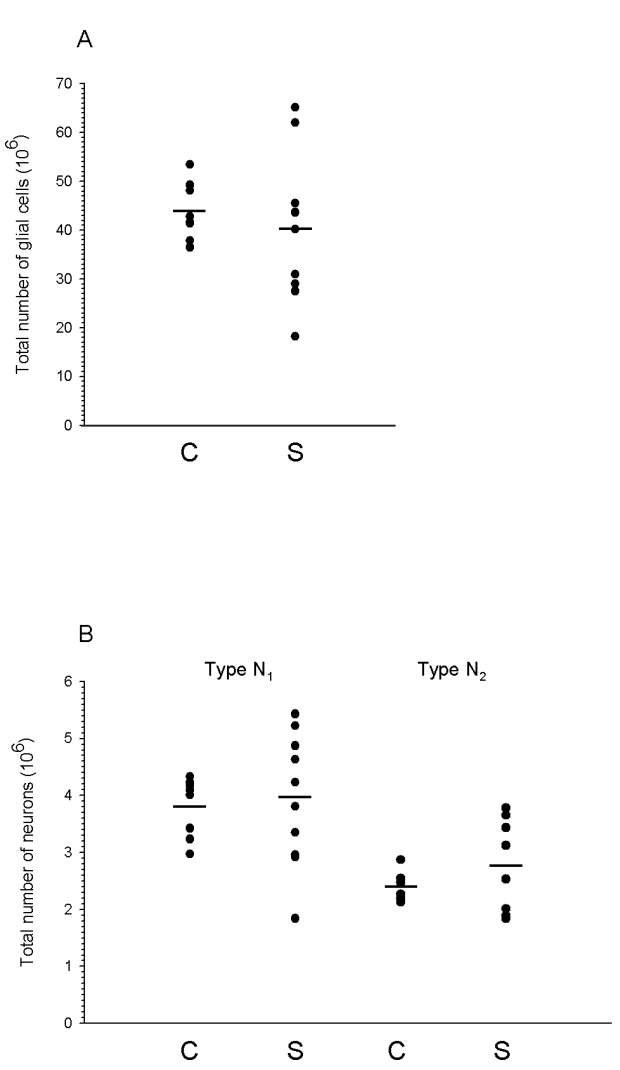

Fig. 3. A: Scatterplot of the estimates of the total number of glial cells in $M D\left(M D_{P C}\right)$ for control $(C)$ subjects and subjects with schizophrenia (S). Horizontal lines indicate mean values B: Scatterplot of the estimates of the total number of relay neurons $\left(N_{1}\right)$ and interneurons $\left(N_{2}\right)$ neurons in the $M D$ for control (C) subjects and subjects with schizophrenia (S). Horizontal lines indicate mean values.

\section{DISCUSSION}

Stereological studies have shown a significant reduction in the total neuron number in the MD of schizophrenic subjects (Pakkenberg, 1990; Popken et al., 2000; Young et al., 2000; Byne et al., 2002), while others (including the present) showed unchanged total neuron number compared to the control subjects (e.g. Cullen et al., 2003; Dorph-Petersen et al., 2004; Young et al., 2004; Kreczmanski et al., 2007). The major limitation in this study is the small number of brains of schizophrenic subjects with a high degree of inhomogeneity in length of disease and age of onset. This was not intented but a matter of availability and strict exclusion criteria regarding the quality of the tissue. However, taking the ongoing debate on the total nerve cell number in schizophrenic subjects and controls into account, we found it of interest to note that the neuronal numbers in the schizophrenic subjects ranged more than a factor of two, from 3.68 to $9.22 \mathrm{x}$ $10^{6}$, which was also reflected in the MD volume, ranging from 177 to $714 \mathrm{~mm}^{3}$ in the schizophrenic subjects. This is in contrast to the control subjects whose neuronal numbers ranged from 5.24 to $7.10 \mathrm{x}$ $10^{6}$, while the volume of the MD ranged from 323 to $696 \mathrm{~mm}^{3}$ for the control subjects. Within our inhomogeneous sample, some schizophrenic patients thus exhibited relative high neuron numbers in $\mathrm{MD}$, while others exhibited relative low neuron numbers. A prior study from our laboratory showed an excess of neurons in the MD of normal newborn brains with a total neuron number of $11.2 \times 10^{6}$ at birth, compared to $6.43 \times 10^{6}$ in the adult brain (Abitz et al., 2007). The selection process by which some neurons survive and other neurons undergo apoptosis during development may thus be interrupted in some yet unknown way in the MD of schizophrenic subjects. If this process is disturbed it may result in mental disease. A higher than normal neuron number could be just as disturbing to the cognitive and affective function of the brain as a lower than normal number. A high biological variance within the schizophrenic group coincides well with the general belief that schizophrenia cannot be attributed to a single factor, but it is in fact a multifactorial disease affected by genetic, developmental, physical and social factors. The debates of the comparison of the number of neurons in the MD in brains of schizophrenic subjects and control subjects and the possible impact of this variance on the disease are still not complete.

Ethic: The Danish Ethical Committee for the community of Copenhagen and Frederiksberg has approved the study (Jr. nr. (KF) 11-123/00).

\section{ACKNOWLEDGMENTS}

We wish to thank professor Edward G. Jones, Center of Neuroscience, University of California, Davis, USA for valuable help in the delineation of the mediodorsal thalamic nucleus and its subdivions and Susanne Sørensen and Hans Jørgen Jensen for their very skilful technical assistance.

\section{REFERENCES}

Abitz M, Damgaard Nielsen R, Jones EG, Laursen H, Graem N, et al. (2007). Excess of neurons in the human newborn mediodorsal thalamus compared to that of the adult. Cereb Cortex 17:2573-8.

Alexander GE, Crutcher MD, DeLong MR (1990). Basal ganglia-thalamocortical circuits: parallel substrates for motor, oculomotor, "prefrontal" and "limbic" functions. Prog Brain Res 85:119-46. 
Armstrong E (1990). Limbic thalamus: Anterior and mediodorsal nuclei. In: Paxinos G, ed. The human nervous system. San Diego: Academic Press, 469-78.

Bäumer H (1954). Veränderungen des Thalamus bei Schizophrenie. J Hirnforsch 1:157-72.

Byne W, Buchsbaum MS, Mattiace LA, Hazlett EA, Kemether E, Elhakem SL, et al. (2002). Postmortem assessment of thalamic nuclear volumes in subjects with schizophrenia. Am J Psychiat 159:59-65.

Cullen TJ, Walker MA, Parkinson N, Craven R, Crow TJ, Esiri MM, et al. (2003). A postmortem study of the mediodorsal nucleus of the thalamus in schizophrenia. Schiz Res 60:157-66.

Danos P, Baumann B, Kramer A, Bernstein HG, Stauch R, Krell D, et al. (2003). Volumes of association thalamic nuclei in schizophrenia: a postmortem study. Schiz Res 60:141-55.

Dewulf A (1971). Anatomy of the normal human thalamus, topometry and standardised nomenclature. Amsterdam: Elsevier.

Dorph-Petersen KA, Nyengaard JR, Gundersen HJG (2001). Tissue shrinkage and unbiased stereological estimation of particle number and size. J Microsc 204: 232-46.

Dorph-Petersen KA, Pierri JN, Sun Z, Sampson AR, Lewis DA (2004). Stereological analysis of the mediodorsal thalamic nucleus in schizophrenia: volume, neuron number, and cell types. J Comp Neurol 472:449-62.

Erickson SL, Lewis DA (2004). Cortical connections of the lateral mediodorsal thalamus in cynomolgus monkeys. J Comp Neurol 20:107-27.

Eriksen N, Pakkenberg B (2007). Quantification of the mysticete neocortex. Anat Rec 290:83-95.

Goldman-Rakic PS, Porrino LJ (1985). The primate mediodorsal (MD) nucleus and its projection to the frontal lobe. J Comp Neurol 22:535-60.

Gundersen HJG (1986). Stereology of arbitrary particles. A review of unbiased number and size estimators and the presentation of some new ones, in memory of William R. Thompson. J Microsc 143:3-45.

Gundersen HJG, Jensen EB, Kieu K, Nielsen J (1999). The efficiency of systematic sampling in stereologyreconsidered. J Microsc 193:199-211.

Hirai T, Jones EG (1989). A new parcellation of the human thalamus on the basis of histochemical staining. Brain Res Brain Res Rev 14:1-34.
Jones EG (1997a). A description of the human thalamus. In: Steriade M, Jones EG, McGormick DA, eds. Thalamus, Vol. II: Experimental and Clinical Aspects. Oxford: Elsevier Science, 425-500.

Jones EG (1997b). Cortical development and thalamic pathology in schizophrenia. Schiz Bull 23:483-501.

Jones EG (2002). Thalamic circuitry and thalamocortical synchrony. Philos Transactions of the Royal Society of London Biolocal Sciences 29:1659-73.

Kreczmanski P, Heinsen H, Mantua V, Woltersdorf F, Masson T, Ulfig N, et al. (2007). Volume, neuron density and total neuron number in five subcortical regions in schizophrenia. Brain 130:678-92.

Monakow, C von (1895). Experimentelle und pathologischanatomische Untersuchungen über die Haubenregion, den Sehhügel und die regio subthalamica. Arch Psychiatr Nervenkrank 27:386-478.

Pakkenberg B (1990). Pronounced reduction of total neuron number in mediodorsal thalamic nucleus and nucleus accumbens in schizophrenics. Arch Gen Psych 47: 1023-8.

Pakkenberg B (1992). The volume of the mediodorsal thalamic nucleus in treated and untreated schizophrenics. Schiz Res 7:95-100.

Popken GJ, Bunney WE Jr, Potkin SG, Jones EG (2000). Subnucleus-specific loss of neurons in medial thalamus of schizophrenics. PNAS 1:9476-80.

Stark AK, Uylings HB, Sanz-Arigita E, Pakkenberg B (2004). Glial cell loss in the anterior cingulate cortex, a subregion of the prefrontal cortex, in subjects with schizophrenia. Am J Psych 161:882-8.

Steriade M, Jones EG, McGormick DA (eds.) (1997). Thalamus, Vol. I: Organisation and Function. Oxford: Elsevier Science 31-126.

Thune JJ, Uylings HB, Pakkenberg B (2001). No deficit in total number of neurons in the prefrontal cortex in schizophrenics. J Psych Res 35:15-21.

Young KA, Manaye KF, Liang C, Hicks PB, German DC (2000). Reduced number of mediodorsal and anterior thalamic neurons in schizophrenia. Biol Psych 1:944-53.

Young KA, Holcomb LA, Yazdani U, Hicks PB, German DC (2004). Elevated neuron number in the limbic thalamus in major depression. Am J Psych 161:1270-7. 